Available online at: http://ejournal-balitbang.kkp.go.id/index.php/ifrj
e-mail:ifrj.puslitbangkan@gmail.com
INDONESIAN FISHERIES RESEARCHJOURNAL
Volume 27 Nomor 2 December 2021
p-ISSN: 0853-8980
e-ISSN: 2502-6569
Accreditation Number RISTEK-BRIN: 85/M/KPT/2020

\title{
MATURITY MEASUREMENT ON BIGEYE SCAD (Selar crumenophthalmus BLOCH 1793) TO INDICATE OVERFISHING
}

\author{
B. Grace Hutubessy ${ }^{1}$ \\ ${ }^{1}$ Fisheries and Marine Science Faculty of Pattimura University \\ JI. Mr. Chr. Soplanit, Kampus Poka, Ambon \\ Received; September 17-2020 Received in revised from July 21-2021; Accepted August 25-2021
}

\begin{abstract}
Bigeye scad (Selar crumenophthalmus) is one of the small pelagic economical species from the family of Carangidae. The annual landing of Carangids in Ambon Island sharply dropped in 2018. Meanwhile, demand for these fish has increased following the local population growth. Was the reduction of fish products showing an indication of overfishing? To answer this, we measured the maturity of bigeye scad caught in Ambon waters during east monsoon (May to July 2019 and March to June 2020), including the length-frequency distribution. We found that the minimum size was $5 \mathrm{~cm}$, the maximum $\left(L_{\max }\right)$ was $23 \mathrm{~cm}$, and the optimum length $\left(L_{\text {opt }}\right)$ was $18.7 \mathrm{~cm}$. The estimated length of first maturity $\left(L_{m}\right)$ of bigeye scad was $18.3 \mathrm{~cm}$. This study showed that the optimum length was slightly longer than maturity length. Less than $30 \%$ of the catch of bigeye scad was immature and indicated a small probability of recruitment overfishing. Arround $57 \%$ of megaspawner found during this study showed more robust broodstocks to produce survival larvae into the population. The possibility of overfishing is relatively low for the bigeye scad fishery during the east monsoon, except for the reduction in the maturity size should be concerned.
\end{abstract}

Keywords: Bigeye Scad; Maturity length; Maximum Length; Optimum size; Overfishing

\section{INTRODUCTION}

Bigeyes (Selar crumenophthalmus BLOCH 1793) is a small-sized species from the Carangids and the most species found among other Scads in Ambon waters. The adult fish prefers clear ocean water and is distributed from islands to neritic waters (Froese \& Pauly, 2012). Meanwhile, the juvenile is frequently found in estuarine waters (Hutubessy, 2001). As pelagic species, these fish swim in groups of hundreds to thousands from coastal waters to a depth of $80 \mathrm{~m}$. Generally, bigeye scad can reach a length of $30 \mathrm{~cm}$, but the common size of the catch is around $20 \mathrm{~cm}$ total length. The main food habit of bigeye scad is plankton and benthic invertebrates (Matsunuma et al., 2011). Juveniles mostly eat crustaceans (Euphausiids, Decapoda), while the adults are active predators for fish larvae and juveniles (Roos et al., 2007). The fish are active during the night for food and spawning (Widodo, et al., 1993).

The exploitation of scad resources (Selar spp) in Maluku has been performed for decades, and it tends to increase (Hiariey, 2009; Matakupan \& Tuapetel,
2017) to support local consumption in the island. High demand for this fish is initiated by the relatively affordable price (Laluraa et al., 2014) and its high nutrient content (Hidayat, 2005; Nurhayati et al., 2007). Bigeye scad is commonly caught using purse seine, lift net, drift gillnet, and hand line (Sangaji et al., 2016) that is more often complemented by fish aggregation devices (locally called as rumpon) and lights. As a nocturnal animal (Widodo et al., 1993) and composed in huge schoolings, bigeye scad is captured in large numbers. The fishing ground is almost evenly spread around Ambon Island (Baskoro et al., 2006; Hiariey, 2009; Nanlohy, 2013). Intensive fishing on bigeye scad around Ambon Island increased concern on the higher landing that would be impacted to risk of depletion. Fisheries statistics of Ambon City reported a significant drop in the landing of trevallies in 2018 following series landing volume which tend to increase gradually since 2007 (BPS Kota Ambon, 2010, 2011, 2012, 2013, 2014, 2015, $2016,2017,2018,2019)$. This reduction was continued by no recorded data of catch in 2019 and 2020 (BPS Kota Ambon, 2020, 2021). The reduction in catch with increased in effort has resulted in a decline in catch- 
per-unit effort, suggesting an occurrence of overfishing that requires a serious monitoring for future fisheries management issues.

Since maturity size is one of the critical parameters in life-history parameters, fishing mortality affects the reproduction pattern of fish. Early maturity as the impact of selective fishing has been reported elsewhere (Robertson et al., 2005; Babcock et al., 2013; Landi et al., 2015). In this study, the size maturity of bigeye scad (Selar crumenophthalmus) was measured as an indicator of overfishing. Studies on this have been conducted in several waters for decades. Kawamoto (1973) reviewed the biology reproduction of bigeye scad in Hawaii and was continued (Clarke \& Privitera, 1995); while Iwai et al., 1996) focused on spawning. Ross et al. (2007) studied the growth and reproduction of bigeye scad from the Reunion Island ship, southeast of the Indian Ocean. Reproduction aspect and length-weight relation of bigeye scad (Selar crumenophthalmus) from Bangaa Faru, Maldives, was also evaluated (Fadzly et al., 2017) following the statement of overfishing on the bigeye scad fishery (Adeeb et al., 2014). In 2015, the population dynamic of bigeye scad from India was studied (Panda et al., 2016). In Indonesia, the analysis of the frequency of bigeye scad was observed (Sadhotomo \& Atmadja, 1985). After more than two decades of break, bigeye scad was overlooked again on the biological aspect (Sangadji et al., 2014) and on fish reproductive biology (Chodrijah \& Faizah, 2019; Fauzi et al., 2018; Lakotany, 2019). Unfortunately, a study focusing on its maturity sizes indicating overfishing has been less accomplished.

This study aimed to evaluate the impact of bigeye scad fishery around Ambon Island through maturity measurement. The maturity stage and first maturity size will be assessed for estimating the optimum length of the catch. Indications of overfishing followed criteria suggested by Froese (2004) will be analyzed and discussed for sustainable fisheries management.

\section{MATERIALS AND METHODS \\ Data collection}

Fish were collected at several fish landings around Ambon Island during the east monsoon (Figure 1), May to July 2019 and March to June 2020. In Ambon, bigeye scads were most captured by purse seine $(43 \%)$, also other gears such as gillnets $(27 \%)$, lift nets $(11 \%)$, beach seine $(3 \%)$, hand lines $(13 \%)$, and other gears (3\%) (DKP Provinsi Maluku, 2012). The total length $(\mathrm{cm})$ and weight $(\mathrm{g})$ were measured by dissecting the body cavity. Gonadal maturity stages were determined following Effendie (1997) and sorted by sampling months.

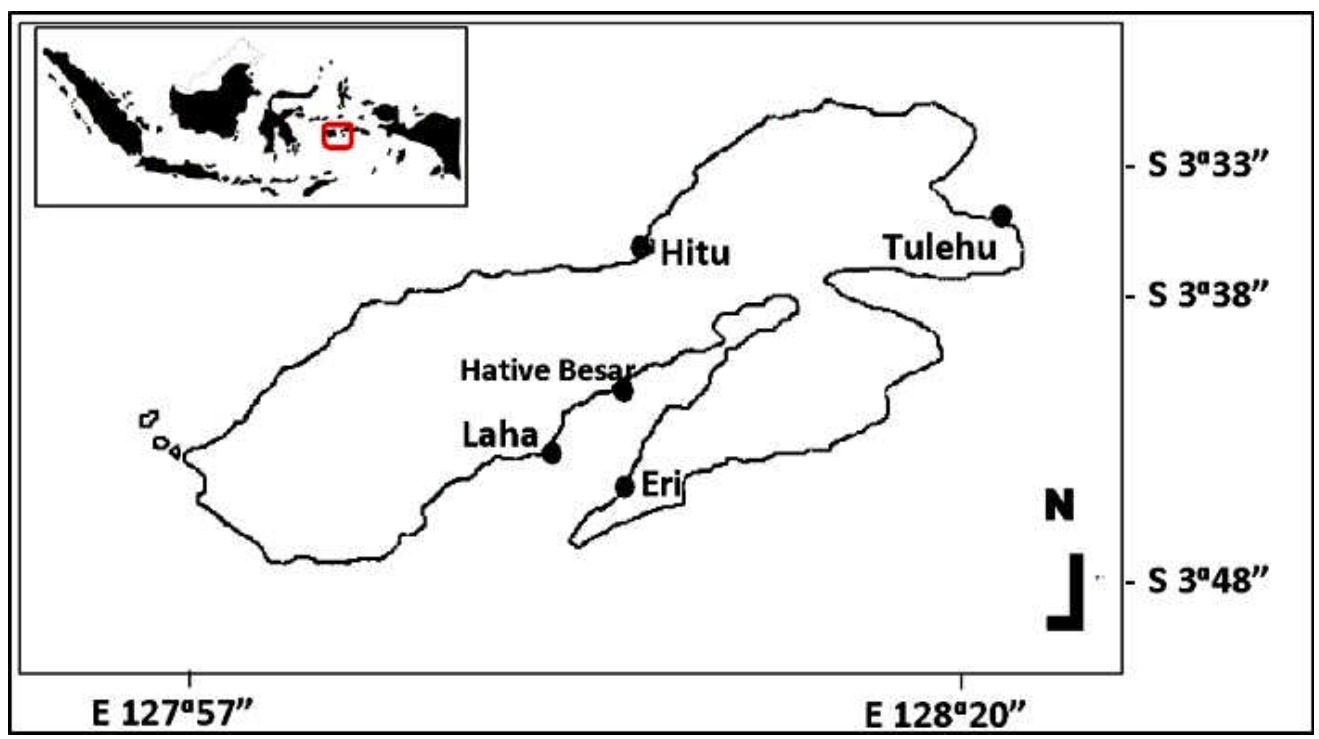

Figure 1. Ambon Island, Maluku Province, Indonesia, and the location of fish landings for bigeye scad (Selar crumenophthalmus).

\section{Data Analyses}

Maturity was determined based on macroscopic appearance of gonads. Fish with maturity stages I and II are categorized as immature and stages III, IV, and $\mathrm{V}$ as mature. Estimation maturity size is calculated based on the proportion of adult fish. The logistic curve may fit the proportion $(P)$ of mature individuals by total length $(L)$, as follows:

$$
P=1 /\left(1+\exp \exp \left[-\mathrm{r}\left(\mathrm{L}-\mathrm{L}_{\mathrm{m}}\right)\right]\right)
$$


With parameter $r$ is the slope of the curve and $L_{m}$ is the mean maturity length, which is linearly transformed between the length and its proportion of maturity (King, 2013). After the maturity size $\left(L_{m)}\right.$ is obtained, the optimum length is estimated using the following equation (Froese \& Binohlan, 2000):

$\log _{10} L_{\text {opt }}=1.053 * \log _{10} L_{m}-0.0565$

\section{Overfishing Indication}

Two components of overfishing (Murawski, 2000): (1) recruitment overfishing: diminishing ability of fish to reproduce, and (2) growth overfishing: catching the fish before reaching the potential growth, are simple to be understood. Froese (2004) proposed three simple indicators to assess the status and trend in the most effective fisheries:

- Indicator 1: 'Let them spawn'. All targets (100\%) should have spawned at least once before they were caught $=P_{\text {mat }}$

- Indicator 2: 'Let them grow'. The proportion (\%) of targets caught at the optimum length (between $0.9^{*} L_{\text {opt }}$ and $\left.1.1^{*} L_{\text {opt }}\right)=P_{\text {opt }}$

- Indicator 3: 'Let mega-spawner live'. More than 20\% of targets is larger than the optimum size $=P_{\text {mega }}$

\section{RESULTS AND DISCUSSION} Results

BPS Kota Ambon (2010-2018) showed that the catch of trevallies fisheries landed in Ambon Island in 2007-2017 increased almost two-fold from 86.2 to 152.1 tonnes (see Appendix A). The decline of the trevallies, which was 31.1 ton in 2018 and followed by no catch data recorded for 2019 and 2020, can be interpreted as depletion stock of trevallies (Heazle \& Butcher, 2007). However, ntil 2014, the utilization of trevallies in Ambon was below the potential sustainability (3789 ton/year) (Matakupan \& Tuapetel, 2017). Meanwhile, the actual condition of small pelagic fisheries in Maluku was reported as over-exploited (Bawole \& Apituley, 2011). herefore, an evaluation should be assessed to understand the real status of trevally fishery. These two later studies were analysed based mainly on catch-per-unit-effort (CPUE) data. Since the use of CPUE data to evaluate the status of stock is considered inappropriate (Maunder et al., 2006), length-based method (Froese, 2004; Babcock et al., 2013) was chosen to assess the fisheries status.

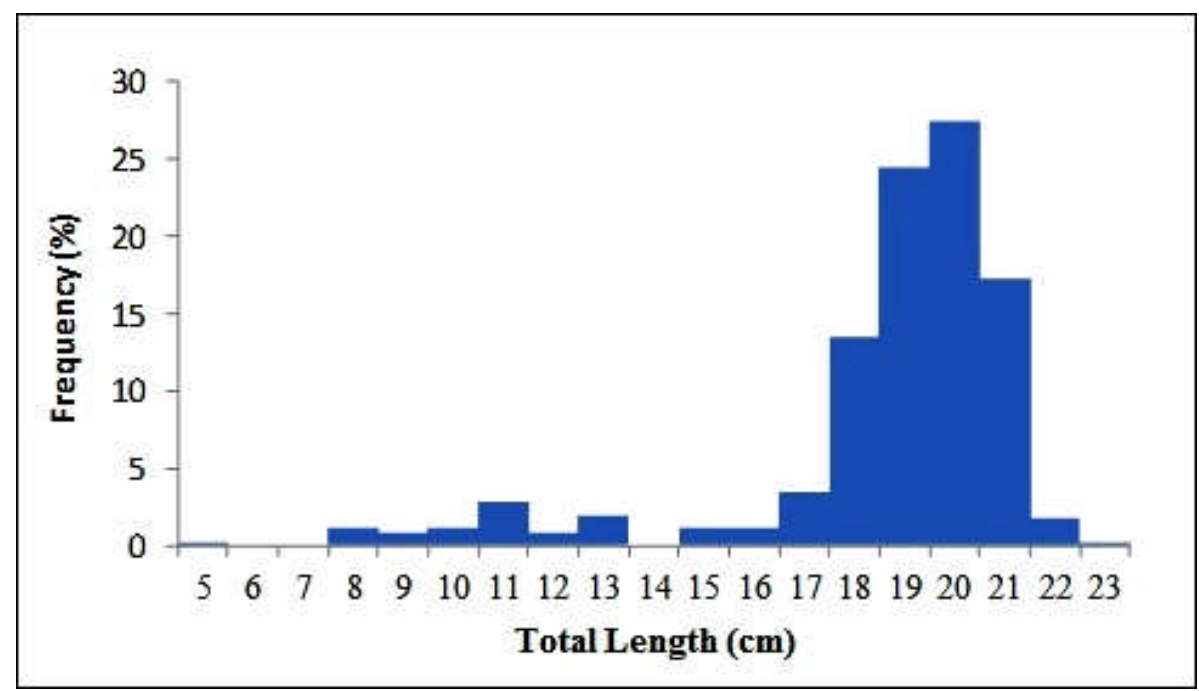

Figure 2. The length distribution of bigeye scad (Selar crumenophthalmus) sampled from Ambon waters.

Length data were collected in 24 days during May to July 2019 and March to June 2020 (east monsoon). A total of 594 individuals of bigeye scad (Selar crumenophthalmus) were identified for the sexual maturity stages. Female fish samples was $39.2 \%$ of the total samples, the male was $43.2 \%$, and unidentified sex was $17.5 \%$.

The length distribution of the sampled fish (Figure. 2) showed positive skewness, meaning more larger fish than small size was captured. The modus' abundant length ranged from $19 \mathrm{~cm}$ to $20 \mathrm{~cm}$. During this study, catch assemblage by gears was not organized, and all samples were combined. Consequently, the samples consisted of fish larger than $14 \mathrm{~cm}$. Fishing practices to catch bigeye scad around Ambon Island was recently dominated by purse seines compared to gillnets and lift nets. Although the mesh size of the bund part is 1 inch (Latar, 2013; Lerebulan, 2019), since fish aggregation devices (rumpon) and light commonly employed during the practice, purse seine is more strategic to produce 
larger fish. The mesh size of gillnet to catch small pelagic fish around Ambon Island is commonly 2 inches (Matrutty et al., 2019), but bigeye scad is not the specific target (Setiawati et al., 2015) due to its infrequent occurrence. Among other small pelagic fishes, such as Indian mackerel (Rastrelliger spp), anchovies (Stolephorus spp), mackerel Scad (Decapterus spp), and mackerel tuna (Euthynnus affinis), the proportion of Selar spp ranged from 4 to $15 \%$ depending on the seasons of each species (BPS Kota Ambon, 2004-2011).

In this study, only mature female fish data were measured in the analysis. Male fish data were exclusive because the male reproductive activity is adapted by social status (Danylchuk \& Tonn, 2001). Female fish of 233 individuals were analyzed, with
103 individuals from 2019 and 130 individuals from 2020. The monthly distribution of maturity stages of female bigeye scad (Fig. 3) signified that monthly spawning is the reproduction strategy of bigeye scad to maintain the population. The 2019 samples showed that mature females were found in May, while only immature females existed in June and July. Compared to the 2020 data, adult females were sampled in March, June, and July but not in April due to the missed sampling on mature females. Based on those limited series data, it is estimated that bigeye scad (Selar crumenophthalmus) spawns every month during the east monsoon. During the rainy season, June to August, nutrient abundantly flows to the ocean due to upwelling process in the Banda Sea (Ikhsani et al., 2016), provided nourishment for the young generation.

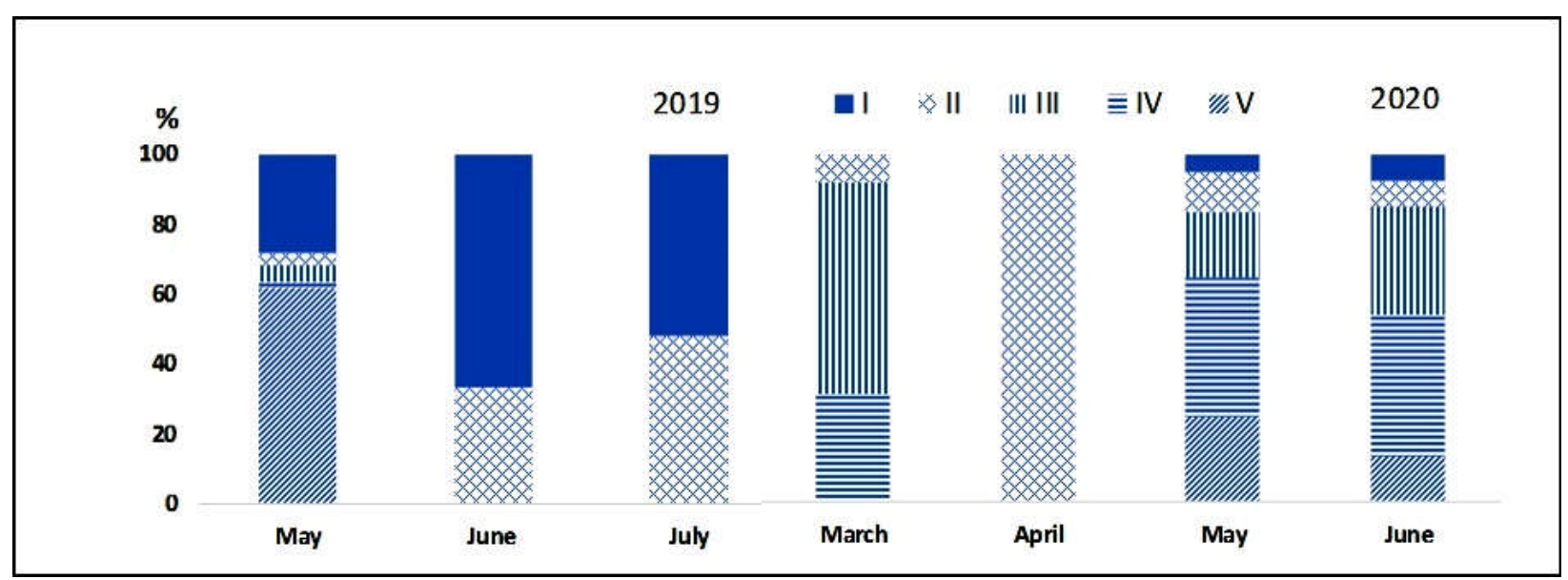

Figure 3. Monthly distribution of maturity stages of bigeye scad (Selar crumenophthalmus) females.

\section{Discussion}

Maturity size is one of the life history parameters that is extremely important in the fisheries management of exploited stocks (Sharpe \& Hendry, 2009). Reduction in maturity size indicates intense selection pressure on fish, such as selective fishing pressure, that has been detected (Jennings \& Kaiser, 1998; Enberg et al., 2012; Pukk et al., 2013). The size at sexual maturity of bigeye scad decreased from $20.1 \mathrm{cmTL}$ in 2019 to $18.3 \mathrm{~cm}$ TLin 2020. The logistic curves describing the relationship between years and the proportion of $50 \%$ maturity (Fig. 4) indicated the decreasing maturity sizes. Increased selective fishing pressure generally tends to affect the size distribution of the adult stock recruited to a fishery by reducing the proportion of large individuals. Since each fishing gear contributes a particular level of selectivity that changes the life history of fish (Liang et al., 2014), multigear strategy used to balance the exploitation has been proposed to be applied (Law et al., 2012; Hutubessy \& Mosse, 2015; Law et al., 2016).
Based on the last maturity size $(18.3 \mathrm{cmTL})$, the determined optimum length is $18.7 \mathrm{~cm}$. To assess the sustainability of a fishery, Froese (2004) suggested three length-based indicators: (1) $P_{\text {mat }}$, the fraction of the catch that is above the length at maturity $\left(L_{\text {mat }}\right)$, (2) $P_{\text {opt }}$, the fraction of the catch that is within $\pm 10 \%$ of the optimal length of harvest $\left(L_{\text {opt }}\right)$, and (3) $P_{\text {mega }}$, the fraction of fish that are more than $10 \%$ larger than $L_{o p t}$ ("mega-spawners"). The bigeye scad fishery in Ambon performed: (1) $P_{\text {mat }}$ is $70.5 \%$, (2) $P_{\text {opt }}$ is $78.6 \%$, and (3) $P_{\text {mega }}$ is $56.9 \%$ (Fig. 5). To avoid recruitment overfishing, Froese (2004) suggested that the fraction of mature fish in the catch should be high, preferably $100 \%$, so that each fish has a chance to spawn at least once before being harvested. This means that the bigeye scad fishery produced a $29.5 \%$ probability of recruitment overfishing. To prevent growth overfishing, all or most of the fish caught should be within $10 \%$ of the optimal length of harvest (Lopt), which is the length at which the biomass of fish in a year-class is maximized. Again, the bigeye scad fishery contributed $21.4 \%$ to growth overfishing. Where possible, 
maximum size limits to avoid capturing any of the mega-spawners would be appropriate because large fish is a critical source of fecundity (Berkeley et al., 2004). In the absence of a maximum size limit, the fraction of mega-spawners in the catch should be more significant than $20 \%$ (Froese, 2004). For the last fraction, the catch of bigeye scad kept almost $57 \%$ of robust broodstock.
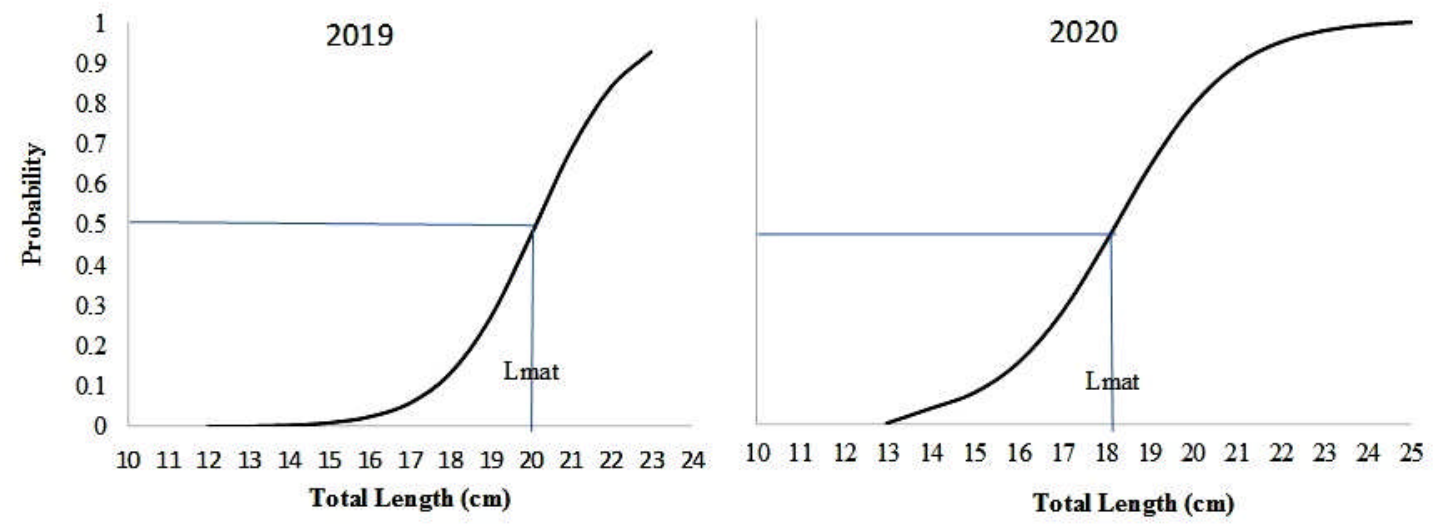

Figure 4. Logistic curves for estimation of size at the first sexual maturity of Selar crumenophthalmus around Ambon Island.

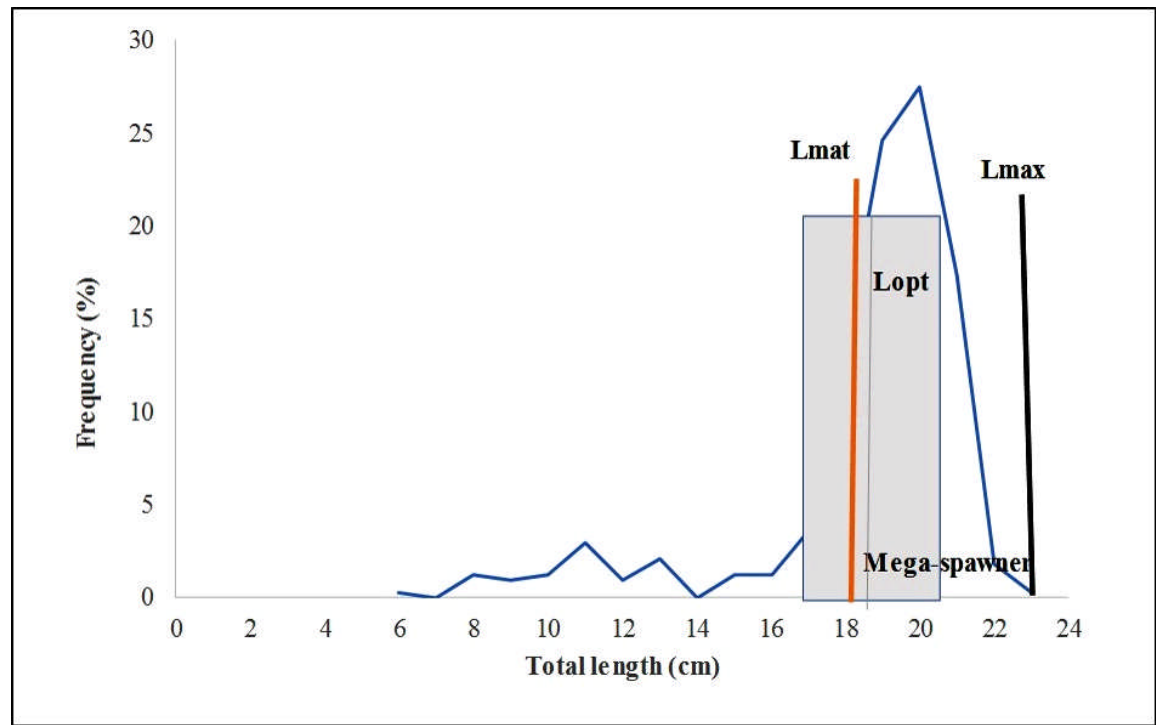

Figure 5. The length-frequency data of bigeye scad collected during east monsoon from 2019 to 2020 in Ambon Island, where $L_{\text {mat }}$ indicates the length at first maturity, $L_{\text {opt }}$ indicates the length range where maximum yield could be obtained. $\mathrm{L}_{\max }$ is the maximum size reached during that time.

The stock of bigeye scad was considered as overexploited by Adeeb et al. (2014) and Panda et al., (2016). Even though it was reported as under-exploited stock by Matakupan and Tuapetel (2017), significantly declined catch in 2018 should be concerned. This study showed occurrence of overfishing in bigeye scad stock, categorised as recruitment overfishing and growth overfishing. The stock of bigeye scad can be regenerated by setting the first maturity size as minimum catch size captured and the optimum size plus $10 \%$ as maximum catch size. This means that a specific gear that captures those intervals of lengths (from minimum to maximum catch size) can be ideally used to sustain the fishery, because protecting the juveniles and mega-spawners will provide successful spawning and, therefore, recruitment stock and spawning biomass may sustain.

\section{CONCLUSIONS}

It is concluded that the indication of overfishing for the fishery of bigeye scad is low. The possibility of recruitment overfishing is less than $30 \%$, and growth overfishing is less than $22 \%$. Selar crumenophthalmus 
is a short life span or fast-growing species and has a continued spawning strategy, and the vulnerability index to capture activity ranges from low to moderate.

\section{ACKNOWLEDGMENTS}

This research was self-funded and involved students of the fisheries department at Pattimura University. Ms. Marhelin Lakotany and Vensly Likumahua, a batch of 2018 students, helped during fish sampling and conducted laboratory works. I thank Professor Jacobus Mosse from Pattimura University for his quality support and suggestions during fieldwork and report writing.

\section{REFERENCES}

Adeeb, S., Fadzly, N., \& Sah, A. S. R. M. (2014). Population Dynamics of Bigeye Scad, Selar crumenophthalmus in Bangaa Faru, Maldives. Journal of Marine Biology \& Oceanography, 03(03). https://doi.org/10.4172/2324-8661.1000133

Babcock, E.A, Coleman, R., Karnauskas, M., \& Gibson, J. (2013). Length-based indicators of fishery and ecosystem status: Glover's Reef Marine Reserve, Belize. Fisheries Research, 147, 434-445. https://doi.org/10.1016/ j.fishres.2013.03.011

Baskoro, M. S., \& Telussa, R.F.Purwangka, F. (2006). Effectiveness of Motorized Lift Net Near Waai, Ambon lisland. (Efektivitas Bagan Motor di Perairan Waai, Pulau Ambon). Prosiding Seminar Perikanan Tangkap,157-165. http:// repository.ipb.ac.id/handle/123456789/25230

Bawole, D., \& Apituley, Y. M. T. N. (2011). Maluku as Nasionala Fish Barn: Policy Review (Maluku Sebagai Lumbung Ikan Nasional/ : Tinjauan Atas Suatu Kebijakan). Prosiding Seminar Nasional, 239-246.

Berkeley, S. A., Chapman, C., \& Sogard, S. M. (2004). Maternal age as a determinant of larval growth and survival in a marine fish, Sebastes melanops. Ecology, 85(5), 1258-1264. https://doi.org/ 10.1890/03-0706

BPS Kota Ambon. (2010). Ambon City in Figures 2010. Ambon: Badan Pusat Statistik Kota Ambon.

BPS Kota Ambon. (2011). Ambon in Figures 2011. Ambon: Badan Pusat Statistik Kota Ambon.
BPS Kota Ambon. (2012). Ambon in Figures 2012. Ambon: Badan Pusat Statistik Kota Ambon.

BPS Kota Ambon. (2013). Ambon in Figures 2013. Ambon: Badan Pusat Statistik Kota Ambon.

BPS Kota Ambon. (2014). Ambon in Figures 2014. Ambon: Badan Pusat Statistik Kota Ambon.

BPS Kota Ambon. (2015). Ambon in Figures 2015. Ambon: Badan Pusat Statistik Kota Ambon.

BPS Kota Ambon. (2016). Ambon Municipality in Figures 2016. Ambon: Badan Pusat Statistik Kota Ambon.

BPS Kota Ambon. (2017). Ambon Municipality in Figures 2017. Ambon: Badan Pusat Statistik Kota Ambon.

BPS Kota Ambon. (2018). Ambon Municipality in Figures 2018. Ambon.

BPS Kota Ambon. (2019). Ambon Municipality in Figures 2019. Ambon: BPS Kota Ambon.

BPS Kota Ambon. (2020). Ambon in Figures 2020. Ambon.

BPS Kota Ambon. (2021). Ambon Municipality in Figures 2021. Ambon: BPS Kota Ambon.

Chodrijah, U., \& Faizah, R. (2019). Biological Reproduction of Bigeye Scad (Selar crimenophthalmus Bloch, 1793) in Kwandang Waters, North Gorontalo (Biologi reproduksi selar bentong (Selar crumenophthalmus Bloch, 1793) Di Perairan Kwandang, Gorontalo Utara). BAWAL Widya Riset Perikanan Tangkap, 10(3), 169. https://doi.org/10.15578/bawal.10.3.2018.169-177

Clarke, T. A., \& Privitera, L. A. (1995). Reproductive biology of two Hawaiian pelagic carangid fishes, the bigeye scad, Selar crumenophthalmus, and the round scad, Decapterus macarellus. Bulletin of Marine Science, 56(1), 33-47.

Danylchuk, A. J., \& Tonn, W. M. (2001). Effects of social structure on reproductive activity in male fathead minnows (Pimephales promelas). Behavioral Ecology, 12(4), 482-489. https://doi.org/ 10.1093/beheco/12.4.482

DKP Provinsi Maluku. (2012). Laporan Statistik Perikanan Provinsi maluku 2012. Ambon: Dinas Perikanan dan Kelautan Provinsi Maluku. 
Effendie, M. I. (1997). Biologi Perikanan (Edisi 1). Yogyakarta: Yayasan Pustaka Nusatama.

Enberg, K., Jørgensen, C., Dunlop, E. S., Varpe, Ø. Boukal, D. S., Baulier, L., ... Heino, M. (2012). Fishing-induced evolution of growth: Concepts, mechanisms and the empirical evidence. Marine Ecology, Vol. 33, pp. 1-25. https://doi.org/10.1111/ j.1439-0485.2011.00460.x

Fadzly, N., Adeeb, S., \& Sah, A. S. R. M. (2017). Some Biological Aspects of Bigeye Scad, Selar crumenophthalmus from Bangaa Faru, Maldives. Tropical Life Sciences Research 28(2), 127-141. (http://creativecommons.org/licenses/by/4.0/

Fauzi, M., Setyobudiandi, I., \& Suman, A. (2018). Reproduction Biology of Bigeye scad (Selar crumenophthalmus Bloch, 1793) In The Natuna Waters of South China sea (Biologi Reproduksi Ikan Selar Bentong (Selar crumenophthalmus Bloch, 1793) di Perairan Natuna, Laut Cina Selatan). BAWAL Widya Riset Perikanan Tangkap, 10(2), 105. https://doi.org/10.15578/ bawal.10.2.2018.105-117

Froese, R., \& Binohlan, C. (2000). Empirical relationships to estimate asymptotic length, length at first maturity and length at maximum yield per recruit in fishes, with a simple method to evaluate length frequency data. Journal of Fish Biology, 56(4), 758-773. https://doi.org/10.1006/ jfbi.1999.1194

Froese, Rainer. (2004). Keep it simple: Three indicators to deal with overfishing. Fish and Fisheries, 5(1), 86-91. https://doi.org/10.1111/ j.1467-2979.2004.00144.x

Froese, Rainer, \& Pauly, D. (2012). FishBase. World Wide Web electronic publication. Retrieved from www.fishbase.org

Heazle, M., \& Butcher, J. G. (2007). Fisheries depletion and the state in Indonesia: Towards a regional regulatory regime. Marine Policy, 31(3), 276-286. https://doi.org/10.1016/ j.marpol.2006.08.006

Hiariey, J. (2009). Exploitation status of Small pelagic fishes from maluku Waters and the fishing capacity (Status eksploitasi sumberdaya ikan pelagis kecil di Perairan Maluku dan kapasitas penangkapannya). Disertation of Institut Pertanian Bogor. 211 pages
Hidayat, T. (2005). Pembuatan hidrolisat protein dari ikan selar kuning (Caranx leptolepis) dengan menggunakan enzim papain. Bogor Agricultural University.

Hutubessy, B. Grace, \& Mosse, J. W. (2015). Ecosystem Approach to Fisheries Management in Indonesia: Review on Indicators and Reference Values. Procedia Environmental Sciences, 23(Ictcred 2014), 148-156. https://doi.org/10.1016/ j.proenv.2015.01.023

Hutubessy, B.G. (2001). Pattern of fish assemblage, age structure and recruitment of tropical estuarine fish. James Cook University of North Queensland.

Ikhsani, I. Y., Abdul, M. S., \& Lekalete, J. D. (2016). Distribusi Fosfat dan Nitrat di Teluk Ambon Bagian Dalam pada Musim Barat dan Timur. Widyariset, 2(2), 86-95.

Jennings, S., \& Kaiser, M. J. (1998). The Effects of Fishing on Marine Ecosystems. Advances in Marine Biology, 34(1798), 201-352. https://doi.org/ 10.1016/S0065-2881 (08)602126

Kawamoto, P. (1973). Management investigation of the akule or big-eye scad, Trachurops crumenophthalmus (Bloch).

King, M. (2013). Fisheries biology, assessment and management. Second edition. (Second Ed.). Australia: Blackwell Publishing Ltd.

Lakotany, M. (2019). Biological Aspect of Bigeye Scad (Selar crumenophthalmus) in Ambon Island Waters (Aspek reproduksi ikan selar bentong (Selar crumenophthalmus) dari perairan Pulau Ambon). Skripsi Universitas Pattimura. 87 hal

Laluraa, L. F. ., Lohoo, H. J., \& Mewengkang, H. W. (2014). IDENTIFIKASI BAKTERI ESCHERICHIA PADA IKAN SELAR (Selaroides sp.) BAKAR DI BEBERAPA RESTO DI KOTA MANADO. Media Teknologi Hasil Perikanan, 2(1). https://doi.org/ 10.35800/mthp.2.1.2014.5359

Landi, P., Hui, C., \& Dieckmann, U. (2015). Fisheriesinduced disruptive selection. Journal of Theoretical Biology, 365, 204-216. https://doi.org/10.1016/ j.jtbi.2014.10.017

Latar, B. S. (2013). Development Strategy on Mini Purse seine in Southeast Maluku (Strategi pengembangan usaha mini purse Maluku 
Tenggara). Program Pascasarjana Universitas Terbuka.

Law, R., Plank, M. J., \& Kolding, J. (2012). On balance exploitation of marine ecosystem: results from dynamic Size Spectra. ICES Journal of Marine Science, 69, 1-13. doi:10.1093/icesjms/fss031

Law, R., Plank, M. J., \& Kolding, J. (2016). Balanced exploitation and coexistence of interacting, sizestructured, fish species. Fish and Fisheries, 17(2), 281-302. https://doi.org/10.1111/faf.12098

Lerebulan, A. (2019). Operation technique and the catch of Purse Seine in Seri village (Teknik pengoperasian dan hasil tangkapan pada alat tangkap purse seine di Dusun Seri). Skripsi Universitas Pattimura, Ambon.

Liang, Z., Sun, P., Yan, W., Huang, L., \& Tang, Y. (2014). Significant effects of fishing gear selectivity on fish life history. Journal of Ocean University of China, 13(3), 467-471. https://doi.org/10.1007/ s11802-014-2167-7

Matakupan Hansje, \& Tuapetel, F. (2017). Potensi Dan Tingkat Pemanfaatan Ikan Kawalinya (Selar spp.) Di Pulau Ambon. Amanisal, 6(2), 16-20. Retrieved from https://ejournal.unpatti.ac.id/ ppr_paperinfo_Ink.php?id=1833

Matrutty, D. D. P., Matakupan, H., Waileruny, W., \& Tamaela, L. (2019). Productivity of drift gillnet based on the time spent fishing in the Inner Ambon bay (Produktifitas jaring insang hanyut berdasarkan waktu tangkap pagi dan sore di Teluk Ambon Dalam). Prosiding Seminar Nasional Kelautan dan Perikanan 2019 Fakultas Perikanan dan IImu Kelautan Unpatti, Ambon. 137-145

Matsunuma, M., Motomura, H., Matsuura, K., Shazili, N. A. M., \& Ambak, M. A. (2011). Fishes of Terengganu East coast of Malay Peninsula, Malaysia. In East. Retrieved from http:// www.museum.kagoshima-u.ac.jp/staff/motomura/ TFG_lowres.pdf

Maunder, M. N., Sibert, J. R., Fonteneau, A., Hampton, J., Kleiber, P., \& Harley, S. J. (2006). Interpreting catch per unit effort data to assess the status of individual stocks and communities. ICES Journal of Marine Science, 63(8), 1373-1385. https:// doi.org/10.1016/j.icesjms.2006.05.008

Murawski, S. A. (2000). Definitions of overfishing from an ecosystem perspective. ICES Journal of
Marine Science, 57(3), 649-658. https://doi.org/ 10.1006/jmsc.2000.0738

Nanlohy, A. C. (2013). The Evaluation of Sustainable Fishing Gear for Pelagic Fish in Maluku Waters by Using Principle of CCRF (Code of Conduct for Responsible Fisheries) (Evaluasi Alat Tangkap Ikan Pelagis yang Ramah Lingkungan di Perairan Maluku dengan Menggunakan Prinsip CCRF ( Code of Conduct for Responsible Fisheries ). Jurnal IImu Hewani Tropika, 2(1), 1-11. https:// www.semanticscholar.org/paper/Evaluasi-AlatTangkap-Ikan-Pelagis-yang-Ramah-di-of-Nanlohy/ 919997f45be85c83affd8daea8b36c95f29090d1

Nurhayati, T., Salamah, E., \& Hidayat, T. (2007). Hydrolysed characteristic of Bigeye Scad protein in enzyme processed. (Hidrolisat Protein Ikan Selar (Caranx Leptolepis) Yang Diproses Secara Enzimatis), Buletin Teknologi Hasil Perikanan 10(1), 23-34. https://doi.org/10.17844/ jphpi.v10i1.966

Panda, D., Jaiswar, A. K., Sarkar, S. Das, \& Chakraborty, S. K. (2016). Growth, mortality and exploitation of bigeye scad, Selar crumenophthalmus off Mumbai, north-west coast of India. Journal of the Marine Biological Association of the United Kingdom, 96(7), 14111416. https://doi.org/10.1017/ S0025315415001459

Pukk, L., Kuparinen, A., Jarv, L., Gross, R., \& Vasemagi, A. (2013). Genetic and life-history changes associated with ûsheries-induced population collapse. Evolutionary Applications, 6, 749-760. doi:10.1111/eva.12060

Robertson, D. R., Choat, J. H., Posada, J. M., Pitt, J., \& Ackerman, J. L. (2005). Ocean surgeonfish Acanthurus bahianus. II. Fishing effects on longevity, size and abundance? Marine Ecology Progress Series, 295, 245-256. https://doi.org/ 10.3354/meps295245

Roos, D., Roux, O., \& Conand, F. (2007). Notes on the biology of the bigeye scad, Selar crumenophthalmus (Carangidae) around Reunion Island, southwest Indian Ocean. Scientia Marina, 71(1), 137-144. https://doi.org/10.3989/ scimar.2007.71n1137

Sadhotomo, B., \& Atmadja, S. B. (1985). On the growth of some small pelagic fish in the Java sea (Pertumbuhan Beberapa Ikan Pelagis Kecil Dari Laut Jawa). Jurnal Perikanan Laut, 33, 53-60. 
Sangaji, M. B., Tangke, U., \& Namsa, D. (2016). Potential and utilization rate of Scads (Decapterus $s p$ ) in Ternate Island Waters (Potensi dan tingkat pemanfaatan ikan layang (Decapterus $\mathrm{sp}$ ) di perairan Pulau Ternate). Agrikan: Jurnal Ilmiah Agribisnis Dan Perikanan, 9(2), 1. https://doi.org/ 10.29239/j.agrikan.9.2.1-10

Setiawati.B, Wijayanto.D, \& Pramonowibowo. (2015). Analisis of Factors Production to Indian Mackerel Catching Used Drift Gill Net in Ketapang Regency, West Borneo (Analisis Faktor Produksi Hasil Tangkapan Ikan Kembung (Rastrelliger Sp) Pada Alat Tangkap Drift Gill Net Di Kab. Ketapang, Kalimantan Barat). Journal of Fisheries Resources Utilization Management and Technology, 4(2), 4048. http://www.ejournal-s1.undip.ac.id/index.php/ jrumt
Sharpe, D. M. T., \& Hendry, A. P. (2009). Life history change in commercially exploited fish stocks: An analysis of trends across studies. Evolutionary Applications, 2(3), 260-275. https://doi.org/ 10.1111/j.1752-4571.2009.00080.x

Widodo, J., Suwarso, \& Suryono, H. (1993). Reproduction Biology and Bigeye Scad (Selar crumenophthalmus, Carangidae) Fishery in Java Sea (Biologi reproduksi dan perikanan selar bentong, Selar crumenophthalmus (Carangidae), di Laut Jawa). Jurnal Penelitian Perikanan Laut, 72, 1-9. 


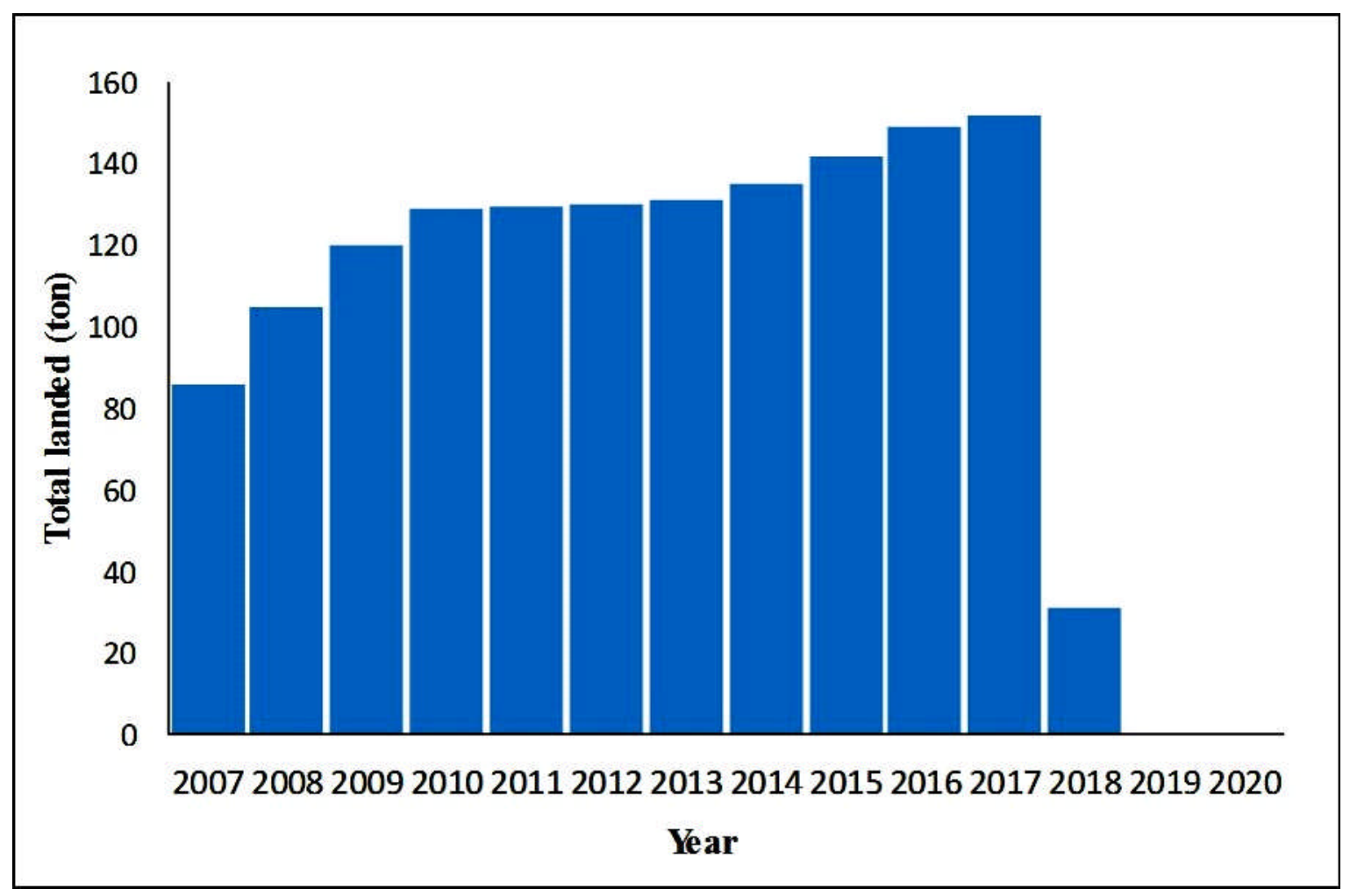

Annual landing of trevallies (Selar spp) from 2007 - 2020 (Source: BPS Kota Ambon 2008-2018) 